\title{
EDWARD SMITH DEEVEY, JR
}

DECEMBER 3, 1914-NOVEMBER 29, 1988

Edward Smith Deevey, Jr died on November 29, 1988, following a heart attack. He was Graduate Research Curator of Paleoecology at the Florida Museum of Natural History, University of Florida, Gainesville. As a reflection of his expertise in many academic disciplines, Ed held Graduate Research Professorships in four University of Florida departments: zoology, botany, geology and Latin American studies.

Ed Deevey was born in Albany, New York on December 3, 1914. He attended Albany High School and the New York State College for Teachers before moving to Yale University where he graduated summa cum laude in 1934. Ed stayed at Yale for his graduate education, receiving his $\mathrm{PhD}$ in 1938 at the age of 23. In the same year, Ed married biological oceanographer Georgiana Baxter with whom he had three children: Ruth, Brian and Kevin. Ed and Georgie shared research interests and co-authored papers on life tables for black widow spiders, zooplankton population dynamics and cladoceran systematics. After Georgie's death in 1982, Ed married Dian Hitchcock, with whom he collaborated on research in atmospheric geochemistry and hydrology of karst-district lakes.

Ed's dissertation, "Typological succession in Connecticut lakes," was completed under (; Evelyn Hutchinson. Following graduation, Ed remained at Yale as a Sterling Post-Doctoral Fellow, before moving to Rice University where he was an instructor in biology from 1939-43. In the latter years of World War II, Ed served as a research associate at Woods Hole Oceanographic Institute, where he studied marine fouling.

Ed returned to Yale and remained as a member of the faculty for more than two decades (1946-68). During this period he was a Guggenheim Fellow and received two Fulbright awards. Ed became Director of the Yale Geochronometric Laboratory in 1951 when the facility was established with the aid of a grant from the Rockefeller Foundation. As a Quaternary scientist with broad-ranging interests (eg, archaeology, lacustrine sedimentology, biogeography), Deevey was quick to promote application of the new absolute dating technique to several disciplines.

In his own research, Ed Decvey used the radiocarbon method to date historical events recorded in lake sediments. Pollen stratigraphies were calibrated, but further, with ages assigned to stratigraphic horizons in sediment cores, interpretations of lacustrine profiles no longer relied on changes in relative abundances of microfossils. Accurate dating allowed calculation of microfossil accumulation rates, thereby providing new insights into historic vegetation cover and lacustrine productivity.

Ed also used isotopic geochemistry to explore interactive biological, geological, and chemical processes in lake waters and sediments. His early collaborative research elucidated the "hard-water-lake" error. Studies in Linsley Pond and other New England lakes revealed how physical, chemical and biological processes conspired to influence the distribution of ${ }^{14} \mathrm{C}$ in waters and underlying muds. 
Ed acknowledged at the outset that Libby's discovery would revolutionize Quaternary studies, but nevertheless maintained a healthy skepticism, and in a 1951 paper co-written with Richard Foster Flint, "Radiocarbon dating of late-Pleistocene events," the authors cautioned readers that 'The new method, like older stratigraphic methods, is subject to possibility of error, recognized and unrecognized, and at present it is impossible to be sure that any opinion about a date, favorable or unfavorable, is free from special pleading. It is therefore necessary, while giving general approval to the new chronology, to keep an open mind about every one of its specific applications.' This gentle warning in no way indicated a lack of enthusiasm for the novel method, and Ed Deevey introduced a wider audience to the new technique with his 1952 Scientific American article titled simply "Radiocarbon Dating." He emphasized that ${ }^{14} \mathrm{C}$ measurement was not only of utility for dating historical events, but would shed light on 'the chemical history of lakes, the atmosphere and the oceans.'

Ed shared editorial duties at Radiocarbon from 1959 to 1971. His long tenure at the Geochronometric Lab and association with the journal led to an historical account of the early days of radiocarbon dating, "Zero BP plus 34: 25 years of Radiocarbon." In this personal reminiscence, published in 1984 , Ed recalled the major players who helped develop the method and establish the Yale facility. He also discussed the methodological problems that were confronted before ${ }^{14} \mathrm{C}$ dating became routine. If our reading of the Deevey recollections is correct, it is safe to say that he felt that the momentous discovery of natural radiocarbon and its quantitative measurements contributed to the integration of the previously distinct disciplines of geology, chemistry and biology under a single heading - biogeochemistry. As a renaissance scholar with expertise in so many fields, Ed Deevey was ideally suited to play a major role in the development and application of the method.

Ed left Yale in 1968, and went to Dalhousie University where he was Kilham Professor of Biology for three years. During his stay in Canada, he served on the Fisheries Research Board of Canada and was a member of the Canadian Committee on the International Biological Programme. He moved to the University of Florida in 1971 and began a major research program investigating the limnology and paleolimnology of lakes in Peten, Guatemala. Under the general heading "Historical Ecology of the Maya," Ed Deevey directed multidisciplinary studies that used archaeological data and lake sediment records to investigate the long-term impact of human settlement on a tropical karst environment. He also used long cores from deep Peten lakes to explore Pleistocene-Holocene climatic change in the lowland Neotropics.

The paleolimnology of karst lake districts became a major focus of his research during his years in Florida, and the general research begun in Guatemala was extended to three other karst areas: Florida, Hispaniola, and most recently the Yunnan Plateau, China. "Hard-water-lake" error, first recognized by Deevey in the $1950 \mathrm{~s}$ as a dating problem, was a potential source of error in all four limestone regions. Further, he recognized that 
much deposited lake sediment in disturbed watersheds is composed of eroded soil with unknown isotopic composition. Sometimes frustrated by anomalous dates, Ed nevertheless felt that such "errors" shed light on the biogeochemical processes that occur in lakes, their airsheds and watersheds. He found consolation in the fact that even the tiniest pieces of terrestrial wood were datable by new accelerator technology.

Ed Deevey belonged to numerous learned and professional societies and held elective office in many of them. He was Chairman of the Aquatic Section of the Ecological Society of America from 1961-64, and was ESA President in 1969-70. He was chosen as the Society's Eminent Ecologist in 1982. Ed served as Vice-President (1958) and President (1974) of the American Society of Limnology and Oceanography. In 1981 he was President of the International Organizing Committee for the 3rd International Symposium on Paleolimnology. Ed also served on the editorial board of a half dozen journals.

Ed Deevey supervised nine doctoral students and seven master's students and sat on the committee on numerous others. His more than 20 postdoctoral research associates include many of the finest Quaternary scientists.

The Deevey bibliography contains well over 100 entries and is remarkable for the depth and breadth of knowledge therein. The topics covered run the gamut, covering among other subjects, pollen analysis, physical, chemical and biological limnology, population ecology, Pleistocene biogeography, paleoclimate, radiocarbon dating, tropical paleolimnology, vertebrate extinctions, mineral cycling, theoretical ecology, and karst hydrology. Ed's publications were seen by scientists from many fields and his writings in Scientific American and New Yorker extended his readership. His contributions were acknowledged by the scientific community in 1981 with his election to the National Academy of Sciences.

Ed Deevey's death is a major blow to the many disciplines that benefited from his numerous contributions, but his passing is felt most acutely by those of us who had the privilege to work with him. Ed's gentle nature and shy demeanor belied his awesome intellect and near-photographic memory. Uncomfortable in the public spotlight, Ed was at his very best in one-on-one discussions. He always took an interest in our personal and professional lives and served as counselor to both. We will miss the seemingly never-ending conversations in his office, punctuated by the relighting of his omnipresent pipe. Ed was always available to answer student questions, and his lengthy replies were frequently filled with personal anecdotes and limpid puns; sometimes the lucky listener was treated to a bawdy limerick.

We have fond memories of the times shared with Ed in the field, and recall particularly the many entertaining and wide-ranging conversations in Peten, Guatemala, held over meals and end-of-day beverages. We frequently discussed the work of the day or natural science topics prompted by the sond of red-winged blackbirds or the habits of jumping spiders. Sometimes, however, the dialogue turned to the ridiculous and we debated in mock seriousness what sort of algal cell or pollen grain the local ashtrays 
most resembled. These happy memories are tinged with the sadness of our recent loss. For many of us, Ed Deevey served as mentor and father figure. We will miss him dearly.

\author{
Mark Brenner \\ Department of Natural Sciences \\ Florida Museum of Natural History \\ Gainesville, Florida 32611 \\ Prudence M. Rice \\ Department of Anthropology \\ University of Florida \\ Gainesville, Florida 32611
}

A SElected Bibliography of

RADIOCARBON AND STABLE ISOTOPE RESEARCH

1951 Deevey, E S and Postzger, J, Peat samples for radiocarbon analysis: problems in pollen statistics: Am Jour Sci, 249:473-511.

1951 Flint, R F and Deevey, E S, Radiocarbon dating of late-Pleistocene events: Am Jour Sci, 249:257-300.

1951 Deevey, E S, A brief discussion of the relation of some radiocarbon dates to the pollen chronology, in Johnson, F, ed, Radiocarbon dating: Mem Soc Am Archaeol, 8:56-57.

1952 Deevey, E S, Radiocarbon dating: Sci American, March, 1952.

1953 Deevey, E S, Utilizzazione del radiocarbonio nella determinazione delle eta geologiche: Rev Sci Preist, 6:115-125.

1953 Blau, M, Deevey, E S and Gross, M S, Yale natural radiocarbon measurements, I Pyramid Valley, New Zealand, and its problems: Science, 118:1-6.

1954 Deevey, E S, Gross, M S, Hutchinson, G E and Kraybill, H, The natural ${ }^{14} \mathrm{C}$ contents of materials from hard-water lakes: Proc Natl Acad Sci, 40:285-288.

1955 Preston, R S, Person, E and Deevey, E S, Yale natural radiocarbon measurements. II Science, 122:954-960.

1957 Barendsen, G S, Deevey, E S and Gralenski, L J, Yale natural radiocarbon measurements. III. Science, 126:908-919.

1958 Deevey, E S, Final report on radiocarbon dating: Office of Naval Research, Contract $609,17 \mathrm{p}$, processed.

1958 Deevey, E S, Radiocarbon-dated pollen sequences in eastern North America: Geobot Inst Rubel, Zurich, Veroffentl, 34:30-37.

1959 Deevey, E S, Gralenski, L J and Hoffren, V, Yale natural radiocarbon measurements IV: Am Jour Sci Radiocarbon Suppl, 1:144-172.

1960 Oana, S and Deevey, E S, Carbon 13 in lake waters, and its possible bearing on paleolimnology: Am Jour Sci, Bradley vol, 258-A:253-272.

1960 Stuiver, M, Deevey, E S and Gralenski, L. J, Yale natural radiocarbon measurements V: Am Jour Sci Radiocarbon Suppl, 2:49-61.

1961 Stuiver, M and Deevey, E S, Yale natural radiocarbon measurements VI: Radiocarbon, $3: 126-140$.

1962 Deevey, E S and Nakai, N, Fractionation of sulfur isotopes in lake waters, in Jensen, M L, ed, Biogeochemistry of sulfur isotopes, Proc NSF symposium, April 12-14, 1962, Yale Univ Dept Geol, p 169-178.

1962 Stuiver, M and Deevey, E S, Yale natural radiocarbon measurements VII: Radiocarbon, $4: 250-262$.

1963 Deevey, E S, Nakai, N and Stuiver, M, Fractionation of sulfur and carbon isotopes in a meromictic lake: Science, 139:407-408.

1963 Stuiver, M, Deevey, E S and Rouse, I, Yale natural radiocarbon measurements VIII: Radiocarbon, 5:312-341.

1963 Deevey, E S, Stuiver, M and Nakai, N, Use of light nuclides in limnology, in Schultz, V and Klement, A W, eds, Radioccology: New York, Reinhold and Washington, AIBS, p $471-475$.

1964 Deevey, E S, Stuiver, M and Nakai, N, Isotopes of carbon and sulfur as tracers of lake metabolism: Proc Internatl Cong Limnol, 15th, Madison, Wisconsin, 1962:284-288.

1964 Deevey, E S and Stuiver, M, Distribution of natural isotopes of carbon in Linsley Pond and other New England lakes: Limnol Oceanog, 9:1-11. 